\title{
Extracorporeal membrane oxygenation support bridge to transplant: Avoiding a bridge to nowhere
}

\author{
Jules Lin, MD
}

\footnotetext{
From the Section of Thoracic Surgery, Department of Surgery, University of Michigan Medical Center, Ann Arbor, Mich.

Disclosures: Author has nothing to disclose with regard to commercial support.

Received for publication July 31, 2017; accepted for publication July 31, 2017; available ahead of print Aug 29, 2017.

Address for reprints: Jules Lin, MD, Section of Thoracic Surgery, 1500 E Medical Center Dr, 2120TC/5344, Ann Arbor, MI 48109-5344 (E-mail: juleslin@umich.edu).

J Thorac Cardiovasc Surg 2017;154:1796-7

$0022-5223 / \$ 36.00$

Copyright $(2) 2017$ by The American Association for Thoracic Surgery

http://dx.doi.org/10.1016/j.jtcvs.2017.07.051
}

The discrepancy in numbers between available donor organs and patients listed for lung transplantation has resulted in increasing mortality for patients on the waiting list. Extracorporeal membrane oxygenation (ECMO) can be used to support patients with respiratory failure. The decision to cross the ECMO bridge to actual transplant can be difficult, however, because of concerns about complications, outcomes, and ethical issues surrounding the use of limited donor lungs. In their article in this issue of the Journal, Todd and colleagues ${ }^{1}$ report a retrospective, single-center experience of 12 patients undergoing ECMO support as a bridge to lung transplant (BTT). All patients successfully underwent transplant, with a 1-year survival of $100 \%$.

Although several centers have reported the successful use of ECMO support as BTT, ${ }^{2-4}$ Biscotti and colleagues ${ }^{2}$ reported only 40 of 72 patients undergoing transplant (55.6\%), with an 84\% 2-year survival. A systematic review of 14 studies including 441 patients showed a 1-year survival of $50 \%$ to $90 \% .^{5}$ Hayanga and associates ${ }^{6}$ evaluated 119 patients by means of United Network for Organ Sharing data and found that 1-year survival of patients receiving ECMO support as BTT increased from $25.0 \%$ in 2000 to 2002 to $74.4 \%$ in 2009 to 2011 but was significantly worse than for patients not receiving ECMO support as BTT.

Although Todd and colleagues ${ }^{1}$ chose to limit their current study to their 1-year experience after establishing a dedicated ECMO program, they do describe 4 patients who were receiving ECMO support as BTT before this study. One patient died while on ECMO support, and another died less than 1 year after transplant, with an overall 1 -year survival of $93.3 \%$. Banga and coworkers ${ }^{7}$ reported that right ventricular dysfunction, worsening renal function, low albumin, and volume overload were associated with poor outcomes. With small numbers and 100\% BTT and 1-year survivals, however, it is difficult to draw any conclusions regarding predictors of poor outcomes from the study of Todd and colleagues. ${ }^{1}$ survival.

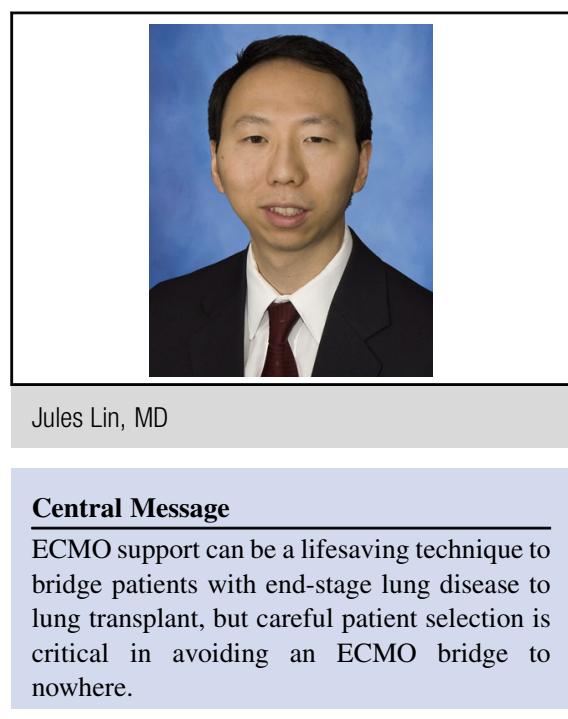

See Article page 1798 .

It was disappointing that no patients were able to ambulate or be weaned from the ventilator. Hoopes and associates $^{4}$ reported on 31 patients receiving ECMO, 19 of whom were ambulatory, and Shafii and colleagues ${ }^{8}$ extubated 6 of $19(33 \%)$ patients who were receiving ECMO. Todd and colleagues ${ }^{1}$ explained that many patients were too deconditioned at the initiation of ECMO. Although some would argue against placing such deconditioned patients, with 2 of them older than 65 years, on ECMO support as BTT, Todd and colleagues ${ }^{1}$ were able to transplant lungs into this entire cohort with $100 \%$ 1-year

The decision to proceed with ECMO support as BTT must include a multidisciplinary team, and multiple factors should be considered, including age, social support, functional status, organ dysfunction, active or resistant infections, risk of bleeding, transplant evaluation status, and factors affecting wait list times, among them size, blood type, transfusions, and panel-reactive antibodies. The decision must be discussed carefully with the patient and family, outlining the possibility of withdrawal from ECMO if the patient is no longer a transplant candidate as a result of complications or deconditioning. As Todd and colleagues ${ }^{1}$ admit, placing 1 patient on ECMO support before the transplant workup was initiated was a risky decision.

Although long-term outcomes are needed and the cohort is small, the reported 100\% 1-year survival is impressive, and Todd and colleagues ${ }^{1}$ are to be commended. ECMO 
support as BTT can be life-saving, and a successful program depends on a dedicated team. Careful patient selection and a thorough and realistic discussion with patients and their families, however, are critical before crossing this bridge to avoid an ECMO bridge to nowhere.

\section{References}

1. Todd EM, Biswas Roy S, Hashimi AS, Serrone R, Panchanathan R, Kang P, et al. Extracorporeal membrane oxygenation as a bridge to lung transplantation: a singlecenter experience in the present era. J Thorac Cardiovasc Surg. 2017;154:1798-809.

2. Biscotti M, Gannon WD, Agerstrand C, Abrams D, Sonett J, Brodie D, et al. Awake extracorporeal membrane oxygenation as bridge to lung transplantation: a 9-year experience. Ann Thorac Surg. 2017;104:412-9.

3. Toyoda Y, Bhama JK, Shigemura N, Zaldonis D, Pilewski J, Crespo M, et al. Efficacy of extracorporeal membrane oxygenation as a bridge to lung transplantation. J Thorac Cardiovasc Surg. 2013;145:1065-70; discussion 1070-1.
4. Hoopes CW, Kukreja J, Golden J, Davenport DL, Diaz-Guzman E Zwischenberger JB. Extracorporeal membrane oxygenation as a bridge to pulmonary transplantation. J Thorac Cardiovasc Surg. 2013;145:862-7; discussion 867-8.

5. Chiumello D, Coppola S, Froio S, Colombo A, Del Sorbo L. Extracorporeal life support as bridge to lung transplantation: a systematic review. Crit Care. 2015; 19:19.

6. Hayanga AJ, Aboagye J, Esper S, Shigemura N, Bermudez CA, D'Cunha J, et al Extracorporeal membrane oxygenation as a bridge to lung transplantation in the United States: an evolving strategy in the management of rapidly advancing pulmonary disease. J Thorac Cardiovasc Surg. 2015;149:291-6.

7. Banga A, Batchelor E, Mohanka M, Bollineni S, Kaza V, Mullins J, et al Predictors of outcome among patients on extracorporeal membrane oxygenation as a bridge to lung transplantation. Clin Transplant. 2017;31 [Epub ahead of print].

8. Shafii AE, Mason DP, Brown CR, Vakil N, Johnston DR, McCurry KR, et al Growing experience with extracorporeal membrane oxygenation as a bridge to lung transplantation. ASAIO J. 2012;58:526-9. 